\title{
CARBON SEQUESTRATION IN EIGHT WOODY NON-TIMBER FOREST SPECIES AND THEIR ECONOMIC POTENTIALS IN SOUTHWESTERN CAMEROON
}

\author{
EGBE, E.A.* - TABOT, P.T. \\ Department of Plant and Animal Science, University of Buea \\ P.O. Box 63 Buea, Cameroon \\ (phone: +237 77671037) \\ Corresponding author \\ e-mail: egbe1@yahoo.com
}

(Received 22 $2^{\text {nd }}$ March 2010; accepted $26^{\text {th }}$ August 2011)

\begin{abstract}
Carbon sequestration potentials of 8 woody species were assessed on an ecosystem level, using the $\mathrm{CO}_{2}$ FIXV.2 model, for two scenarios. Net carbon sequestration potentials ranged from 246.23 to 306.22 Mg C ha ${ }^{-1}$ with complete rotation every 40 years, and 292 to $359.3 \mathrm{Mg} \mathrm{C}^{-1}$ with partial cut. Ricinodendron heudelotii had the highest net carbon sequestration potential (306.22 and $359.3 \mathrm{Mg} \mathrm{C}^{-1}$ for the complete and partial cuts respectively), while Cola lepidota had the least under both scenarios. There were higher carbon stocks in plant biomass than soil for all agroforests under both management regimes. Fine litter had the highest soil carbon fraction and soluble compounds had the least in all the agroforests. Under complete rotation, the agroforests had potential carbon credit values ranging from US $\$ 2756$ to $\$ 3264 /$ ha/rotation, and \$ 3114 to $\$ 3678 /$ ha/rotation with partial cut. Partial cuts allowed for higher rates of carbon accumulation, and the farmer always has a standing crop. Economic prioritization showed that Irvingia wombulu was the best (US\$6.67/Kg), followed by Ricinodendron heudelotii and Afrostyrax lepidophyllus $(\$ 5.55 / \mathrm{Kg})$ and the least was Trycocypha abut $(\$ 0.33 / \mathrm{Kg})$. These results would aid policy makers in mitigating climate change, improving rural livelihoods, and contributing to sustainable development.
\end{abstract}

Keywords: carbon stocks, $\mathrm{CO}_{2}$ FIXV.2 model, sustainability, climate change and carbon trade

\section{Introduction}

Forests are long-lived dynamic systems that are involved in climate regulation. Cameroon's forest (22 million hectares) is of economic, cultural and socio-political importance to the countries of the Congo basin, and of ecological and scientific interest to the rest of the world (Djeumo, 2001). According to Fomete (2001) logging of timber represents approximately $25 \%$ of the country's exports. However, agriculture is the main economic activity of more than $80 \%$ of of the 16 million inhabitants, with both subsistence and extensive plantation schemes. Large expanses of tropical forests are cut yearly to make way for these plantations. This coupled with the agricultural method of slash and burn, poses a threat to the biodiversity of the region, degrades the soil, and emits enormous amounts of greenhouse gases (GHGs). The Global Canopy Program estimates that deforestation accounts for $80 \%$ of greenhouse gases. Greenhouse gas emissions and the potential for climate change are the focus of increasing international concern (Cacho et al., 2003; Mutuo et al., 2005; Stern, 2006). However, enhanced greenhouse effect can be mitigated by reducing carbon sources or increasing carbon sinks. Karjalainen et al. (2002) have reported that terrestrial carbon sinks can be strengthened either by increasing the density of vegetation cover in currently vegetated areas or increasing the area covered by vegetation. The former can be achieved by in- 
situ conservation and enrichment of woody non-timber forest products (NTFPs) in their natural habitats, and the latter by establishment of agroforestry/plantation schemes in deforested areas.

Agroforestry is eligible under the clean development mechanism of the Kyoto Protocol if carried out on land deforested prior to 1990. Sales of carbon credits will consequently represent both an incentive for conservation and an added value to agroforest systems. But there is lack of empirical data on the carbon sequestration potential of different species, which limits the feasibility of initiating carbon-offset projects (Glenday, 2006; Shin et al., 2007).

This paper evaluates the carbon stocks in eight important woody NTFPs in Southwestern Cameroon under two management regimes (complete and partial cut), it also compares the impacts of farm management on the carbon stocks of different pools, and uses the income-generating potentials of the different NTFPs to determine species with best ecological and economic value.

\section{Materials and methods}

\section{Study site}

The study was carried out in Manyu Division of Southwestern Cameroon. Manyu Division lies at the northwestern end of the region, bordered by UTM coordinates 48234, 629115m to the West, 597372, $615667 \mathrm{~m}$ to the East, 572470, $722248 \mathrm{~m}$ to the North and 522168, $586781 \mathrm{~m}$ to the South (all UTM values based on the N32,WGS 24 base datum). It covers a surface area of about 945720.6 ha. It is a low plateau with undulating topography and an altitude of 135 to $1000 \mathrm{~m}$ (Nkwatoh, 2000).

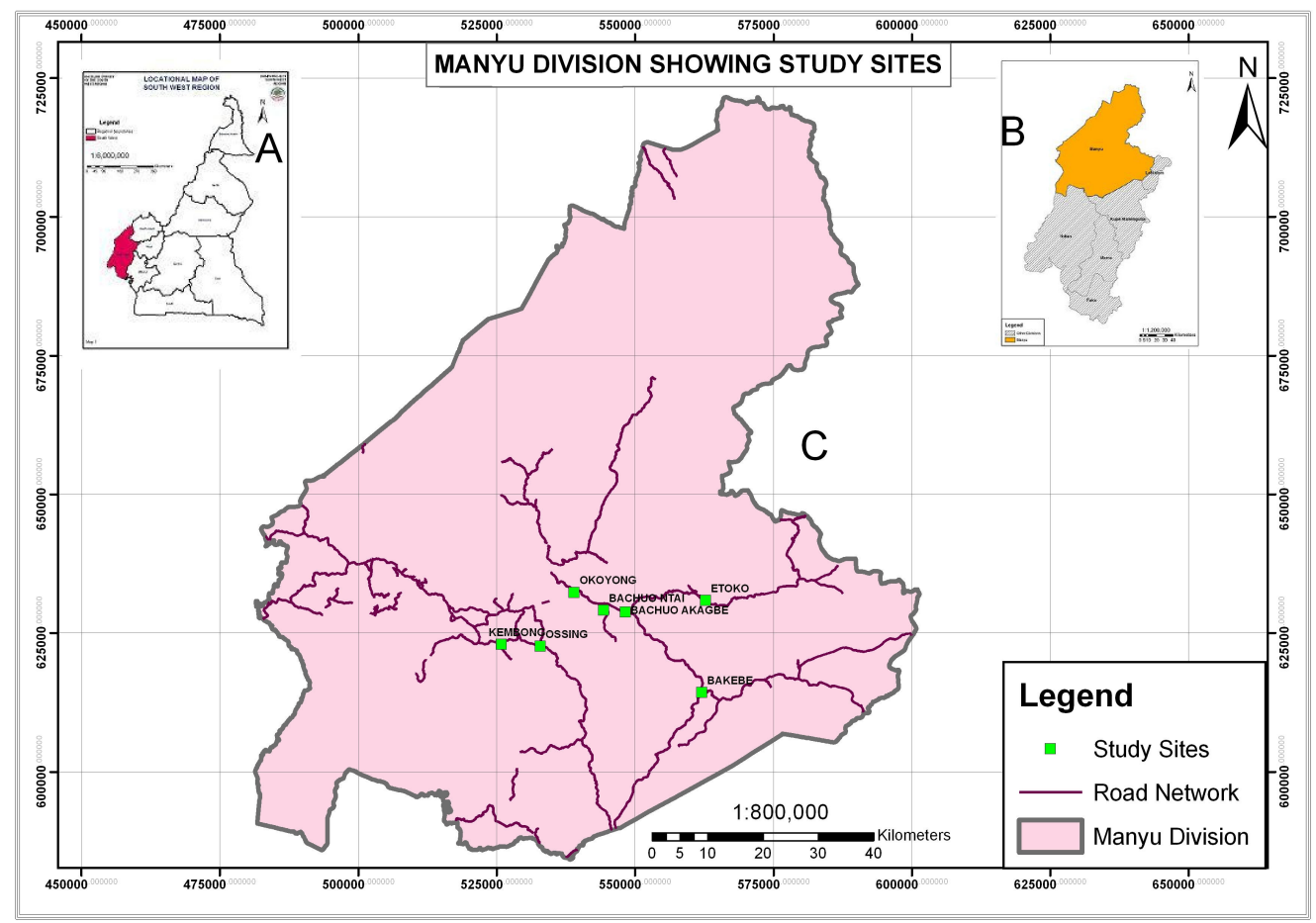

Figure 1. A: Map of Cameroon; B: Map of Southwest region and C: Map of Manyu division showing the study sites 
There are two seasons, a dry season from November to March, and a wet season from April to October. Mean annual rainfall of 2000-2500 $\mathrm{mm}$ is recorded, with a mean annual temperature range of 26 to $35^{\circ} \mathrm{C}$. The natural vegetation is the lowland equatorial rainforest, interspersed with secondary regrowth as a result of agricultural practices and logging of timber in some areas. Its forests have a higher diverse flora, richer in species than any other African rainforest for which comparable data are available (Nkwatoh, 2000). The soils are acidic and predominantly sandy-loam which are heavily leached as a result of low water retention capacity and frequent heavy rainfall. Agriculture is the main economic activity, with previously large expanses of vegetation replaced by agroforestry schemes ranging from subsistence farms and smallholder schemes to private plantations.

\section{Methods}

A reconnaissance survey was carried out to select possible study locations. Eight locations were selected namely, Bakebe, Bachuo-Akagbe and Etoko, all in Upper Banyang subdivision; Okoyong, Bachuo-Ntai and Besongabang in Mamfe Central subdivision as well as Kembong and Ossing in Eyumojock subdivision (Fig. 1). The selection of study locations was based on the population, farming practices and accessibility. Leaders of farmers' groups and guides were identified in the various locations.

The study species were Bitter cola (Garcinia cola), Dry season bush mango (Irvingia wombulu), Rainy season bush mango (Irvingia gabonensis), Monkey cola (Cola lepidota), Plum (Dacryodes edulis), Okoyong fruit (Trichocypha abut), Njangsa (Ricinodendron heudelotii) and contry onion (Afrostyrax lepidophyllus).

Plant parameters determined included stem diameter, height and wood density. An average of 50 plants per species and a total of 400 plants were measured, in the field. Stem diameters were measured at breast height (Masera et al., 2003), using a diameter tape. Plant heights were measured using a $2 \mathrm{~m}$ range pole and estimated by the ruler method. This method was preferred to the altimeter-based measurement because of the closed canopy in most of the study sites. Standing volumes were calculated (at $R^{2}>90$ $\%$ and standard error $=1.283$ ) from the dbh using the power 2 equation in Eba'a Atyi (2000) below:

$$
V=8.872(D B H)^{2.270}
$$

Where:

$\mathrm{V}=$ standing volume, and

$\mathrm{DBH}=$ Diameter at breast height.

The diameters were graded into five classes based on the life stage of the plants (biomass/maximum biomass), for each species, and the current annual increments calculated as the difference in volume between successive stages. Turnover rates were used for roots (0.05), branches (0.05) and leaves 0.6-0.8) based on field observations.

Leaf litter was collected from three $50 \times 50 \mathrm{~cm}$ quadrats set randomly at the base of the plants, within one metre from the tree. In each quadrat, all litter was collected and the leaf litter of the species sorted out and bulked in labelled polybags. The litter was weighed, and sub samples of $200 \mathrm{~g}$ put in aluminium foil and oven-dried at $60{ }^{\circ} \mathrm{C}$ for 72 
hours, then reweighed. These samples were then milled in a plant mill and sieved in a $1 \mathrm{~mm}$ sieve. Organic carbon was determined by ashing $10 \mathrm{~g}$ of the milled sample in a Kendro furnace at $550{ }^{\circ} \mathrm{C}$ for 2 hours (Gallardo et al., 1987; Delaney et al., 1997; Matthiessen et al., 2005). The carbon content of the litter was calculated as the difference between the oven-dried mass and the resultant ash.

Soil samples were collected systematically from one metre from the stands of each species and from newly cleared adjacent forest, and used to determine the initial situation of soil carbon at the time of establishment of these agro-ecosystems. Soil samples were collected from three depths viz 0-10, 10-20 and 20-30 cm using a soil auger. Soil samples of the same depth were bulked into labelled polybags. These samples were air-dried for three weeks, sieved in a $2 \mathrm{~mm}$ sieve, and further dried in an oven at $105^{\circ} \mathrm{C}$ for 72 hours. The carbon content was determined by ashing $10 \mathrm{~g}$ of the soil in a Kendro furnace at $550{ }^{\circ} \mathrm{C}$ for 2 hours. The carbon content of the soil was calculated as the difference between the oven-dried mass and the resultant ash. All carbon values were expressed as a percentage of the soil mass for the plough layer per hectare $\left(2 \times 10^{6} \mathrm{Kg} / \mathrm{ha}\right)$. The soil module of CO2FIXV.2 was adjusted for the specific study location by adjusting the potential evapotranspiration based on mean monthly temperature and mean monthly rainfall for the year 2006.

Wood densities of the different species were determined according to the methodology established by Delaney et al. (1997). For plants whose stems could not be got, average wood density values were gotten from Gisel et al. (1992). The resulting data were used as inputs into the CO2FIXV.2 model for carbon stocks simulations.

Carbon stocks were simulated as a function of tree size, using the CO2FIXV.2 approach. This is an ecosystem-based method in which complete carbon accounting is applied (Masera et al. 2003). Two management regimes were simulated, that is, complete rotation in which all the plants are cut and simultaneously replanted every 40 years, and partial cut in which half of the plantation is cut and simultaneously replanted every 40 years, while the other half continues production for another 10 years before being cut. We term this intervening 10 years between the first half-cut and the second a 'shunt gap'. The simulation length, which is the entire duration of cultivation at the same site, was 200 years, while the rotation length/period which is the economic lifespan of the plantation, is 40 years. The rate of carbon accumulation was calculated by dividing the stock at any time interval, by the time elapsed (Eq.1):

$$
\operatorname{Rc}=\frac{C t}{t}
$$

where $\mathrm{Rc}$ is the rate of carbon accumulation, $\mathrm{Ct}$ is the carbon stock at time $\mathrm{t}$, and $\mathrm{t}$ is the time elapsed.

The value of sequestered carbon in the international market was determined by multiplying the mean carbon stock for the rotation by $\$ 10$ (mean price per $\mathrm{Mg} \mathrm{C}$ ) (Eq.2 and Eq.3):

$$
\mathrm{X}=\mathrm{Cm} \times \$ 10
$$

and

$$
\mathrm{Cm}=\frac{C 1+C 2+C 3+C 4+C 5}{5}
$$


where $X$ is the cash value of sequestered carbon, $\mathrm{Cm}$ is the mean carbon stock $(\mathrm{Mg} / \mathrm{ha})$ for a rotation, and $\mathrm{C} 1, \mathrm{C} 2, \mathrm{C} 3, \mathrm{C} 4$ and $\mathrm{C} 5$ are the carbon stocks at the end of the different cycles, $\$=\mathrm{US}$ dollars.

Net carbon stocks were calculated by subtracting the carbon stock at the end of the simulation period from the initial carbon stock in the system, and used in the determination of 'best ecology and best economy model'.

The economic value of the different species was evaluated using semi-structured questionnaires. Participatory rural appraisal (PRA) was used to administer an average of 30 questionnaires in each of the study locations, making a total of 240 questionnaires. For the purpose of this paper, only the farm gate prices of produce were used, for the economic potentials of these plants. Farm gate prices were determined from the selling price of produce per kilogram at the various sites. Multivariate analysis was used to determine species with best income-generating and carbon sequestration potentials.

\section{Results}

At the end of the simulation period, total carbon stocks ranged from 277.38 to 337.37 $\mathrm{Mg}$ ha $^{-1}$ with complete rotation and 323.15 to $390.45 \mathrm{Mg} \mathrm{ha}^{-1}$ with partial cut. Ricinodendron heudelotii was found to have the highest carbon sequestration potential of all species studied, while Cola lepidota had the least under both regimes. Under complete rotation, $R$. heudelotii would sequester $300.36 \mathrm{Mg} \mathrm{C}^{-1}$ in biomass while Cola lepidota had the least potential and sequesters $247.42 \mathrm{Mg} \mathrm{Cha}^{-1}$ (Fig. 2). In partial cut, biomass carbon stocks in the first rotation ranged from 125.97 to $152.69 \mathrm{Mg} \mathrm{C} \mathrm{ha}^{-1}$, with $R$. heudelotii having the highest and Cola lepidota the least stock. Carbon stocks in plant at the fifth rotation ranged from 147.84 to $173.43 \mathrm{Mg} \mathrm{C} \mathrm{ha}^{-1}$ with the highest stock in R. heudelotii and the least in Cola lepidota agroforests (Fig. 3).

Under complete rotation total soil carbon stocks in the first rotation ranged from 53.38 to $75.36 \mathrm{Mg} \mathrm{C}^{-1}$ and in the fifth rotation it had a range of 56.87 to $81.25 \mathrm{Mg} \mathrm{C}$ ha $^{-1}$ with $R$. heudelotii having the highest, and D. edulis the least stock in both situations (Fig. 4). The first rotation under the partial cut regime had a range of 35.62 to $63.5 \mathrm{Mg} \mathrm{C}$ $\mathrm{ha}^{-1}$, while the fifth rotation had a range of 43.84 to $72.29 \mathrm{Mg} \mathrm{C} \mathrm{ha}^{-1}$ and $G$. cola had the highest, and A. lepidophyllus the least stock in both situations (Fig. 5). Tables 1a and 1b show soil carbon stocks in the various fractions under the different management regimes. Fine litter had the highest carbon stock, followed by humus and coarse litter, non-woody litter, holocellulose, lignin and soluble compounds, for most of the species; except for $R$. heudelotii. In complete rotation, the carbon stocks in the different soil carbon fractions in $R$. heudelotii had the following trend; coarse litter $\left(170.11 \mathrm{Mg} \mathrm{C}^{-}\right.$ $\left.{ }^{1}\right)>$ fine litter $\left(34.49 \mathrm{Mg} \mathrm{C} \mathrm{ha}^{-1}\right)>$ humus $\left(28.67 \mathrm{Mg} \mathrm{C} \mathrm{ha}^{-1}\right)>$ non-woody litter $(11.42$ $\left.\mathrm{Mg} \mathrm{C} \mathrm{ha}{ }^{-1}\right)>$ holocellulose $\left(2.63 \mathrm{Mg} \mathrm{C} \mathrm{ha}^{-1}\right)>\operatorname{lignin}\left(2.16 \mathrm{Mg} \mathrm{C} \mathrm{ha}^{-1}\right)>$ soluble compounds (1.33 Mg C ha $\left.{ }^{-1}\right)$. In Cola lepidota with the least stocks, the trend was fine litter $\left(20.66 \mathrm{Mg} \mathrm{C} \mathrm{ha}^{-1}\right)>$ humus $\left(17.3 \mathrm{Mg} \mathrm{C} \mathrm{ha}^{-1}\right)>$ coarse litter $\left(7.82 \mathrm{Mg} \mathrm{Cha}^{-1}\right)>$ non woody litter $\left(7.76 \mathrm{Mg} \mathrm{C}^{-1}\right)>$ holocellulose $\left(1.82 \mathrm{Mg} \mathrm{C}^{-1}\right)>\operatorname{lignin}\left(1.51 \mathrm{Mg} \mathrm{C}^{-}\right.$ $\left.{ }^{1}\right)>$ soluble compounds $\left(0.94 \mathrm{Mg} \mathrm{C} \mathrm{ha}^{-1}\right)$. Under the partial cut regime, $R$. heudelotii had soil carbon fractions with the range of 1.36 to $98.94 \mathrm{Mg} \mathrm{C} \mathrm{ha}^{-1}$ with coarse litter $>$ humus $>$ fine litter $>$ non woody litter $>$ holocellulose $>$ lignin $>$ soluble compounds. The pattern of carbon fractions in Cola lepidota showed that humus had the highest stock (19.52 $\left.\mathrm{Mg} \mathrm{C} \mathrm{ha}^{-1}\right)$ and soluble compounds the least (0.94 $\left.\mathrm{Mg} \mathrm{C} \mathrm{ha}^{-1}\right)$. 


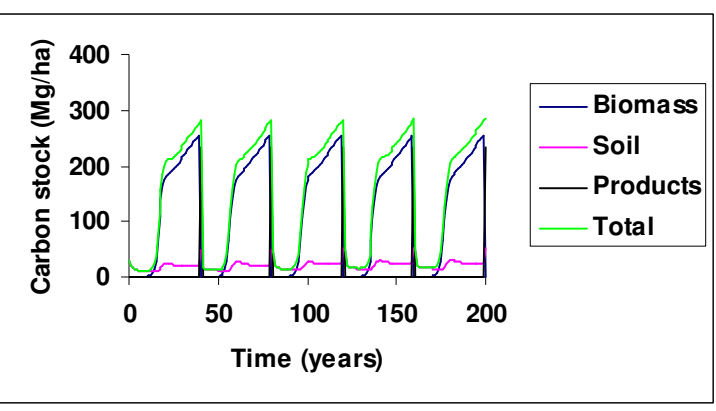

a) A. lepidophyllus

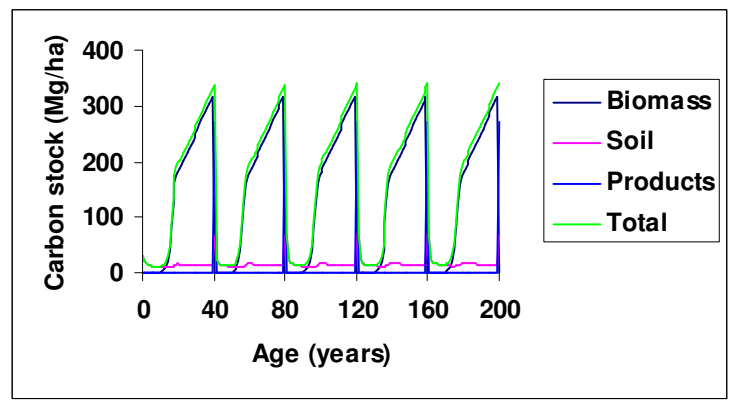

c) D. edulis

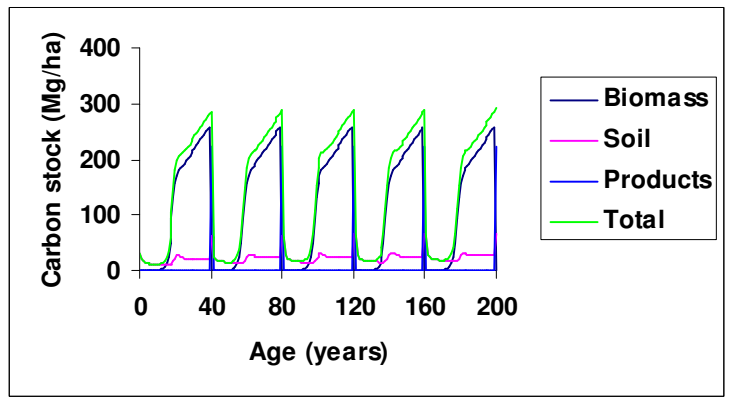

e) I. gabonensis

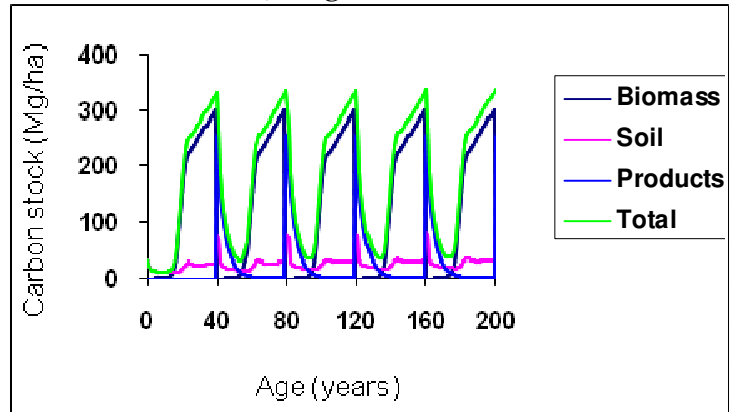

g) R. heudelotii

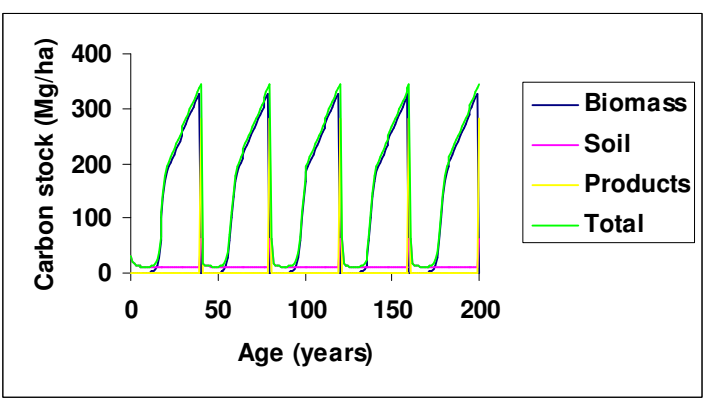

b) C. lepidota

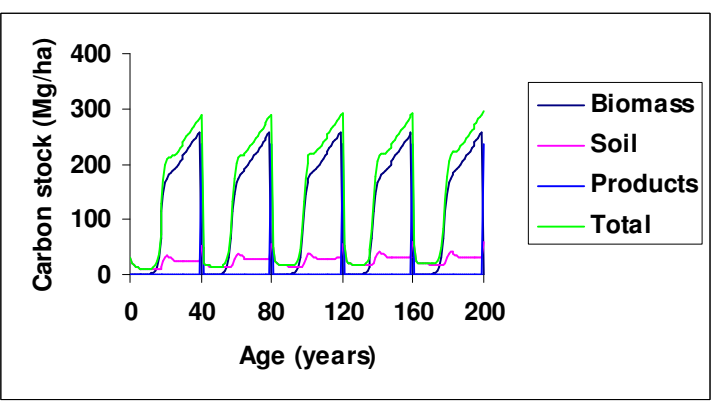

d) G. cola

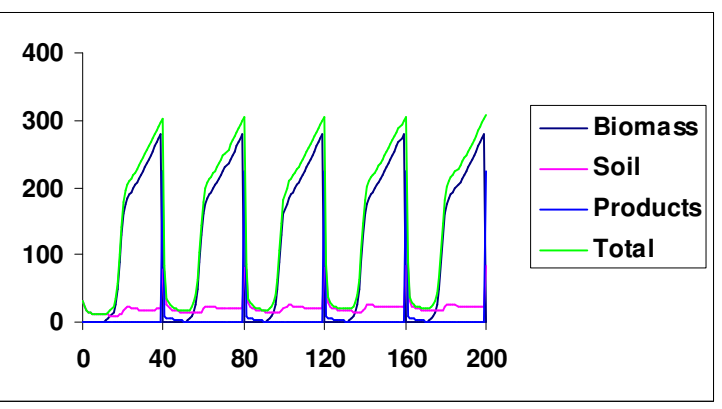

f) I. Wombulu

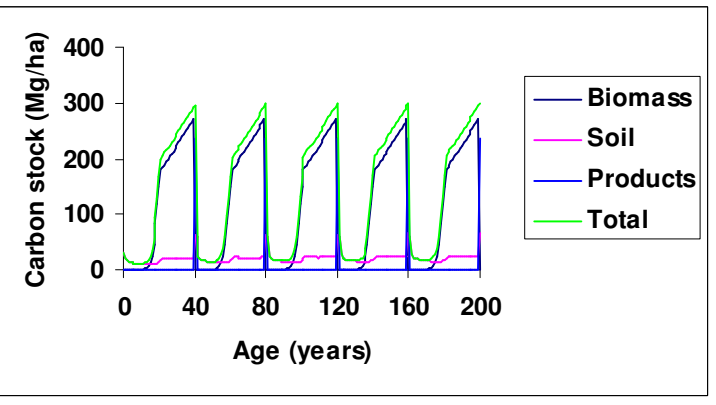

h) T. abut

Figure 2. Carbon sequestration in the different agroforests with complete rotation every 40 years, for five cycles 


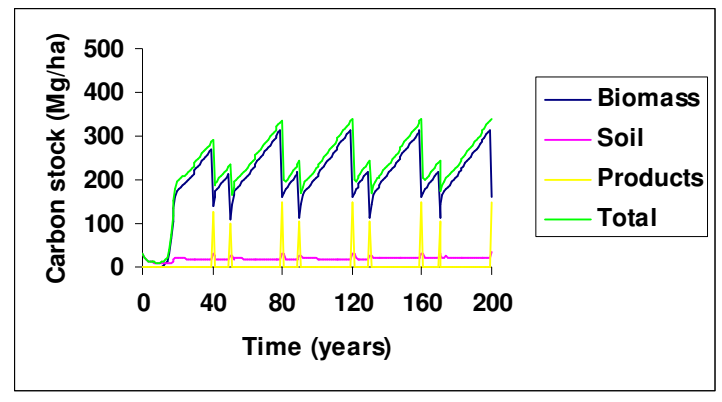

a) A. lepidophyllus

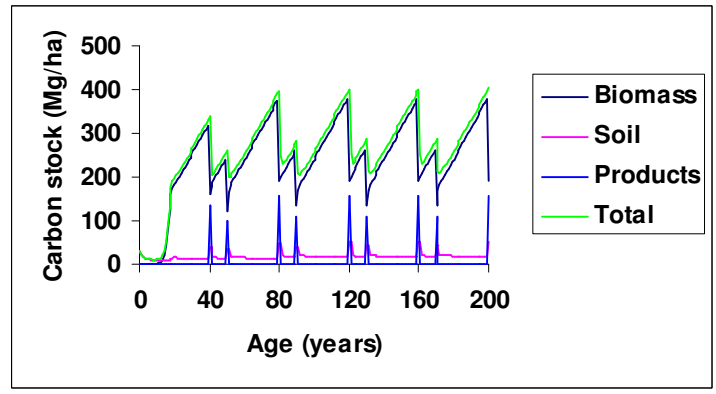

c) D. edulis

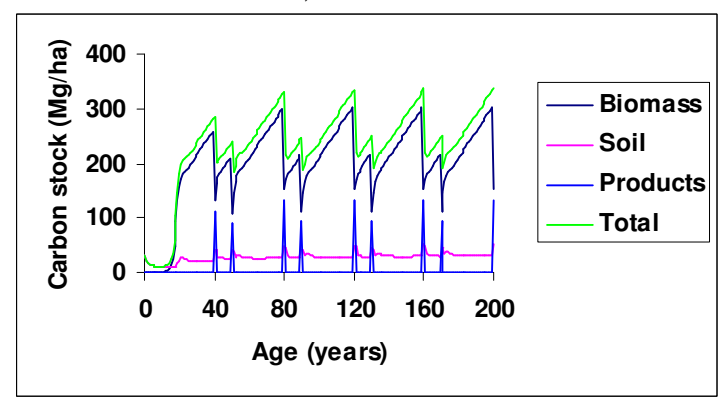

e) I. gabonensis

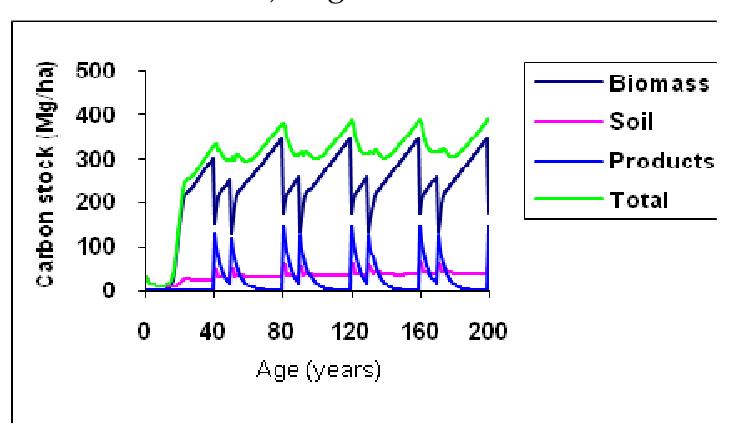

g) R. heudelotii

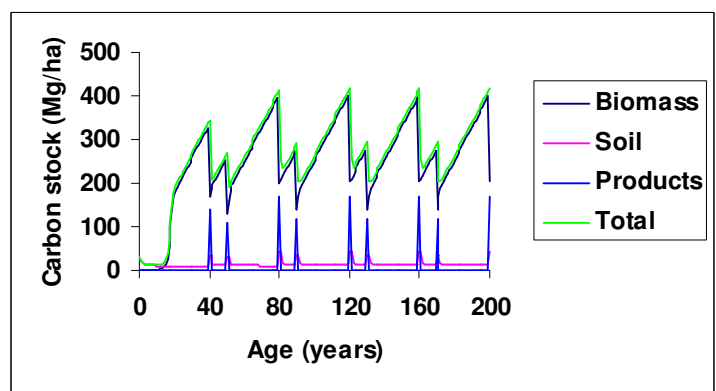

b) C. lepidota

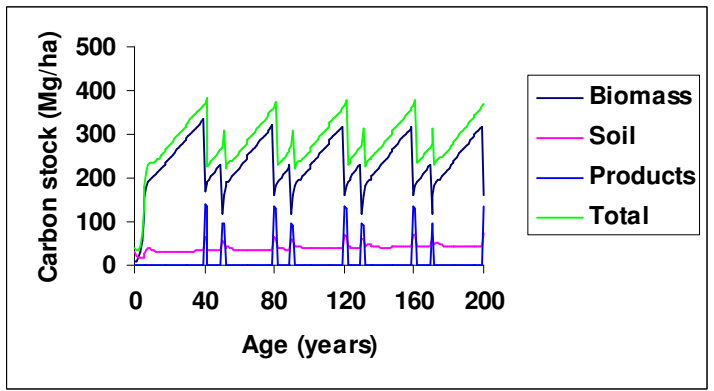

d) G. cola

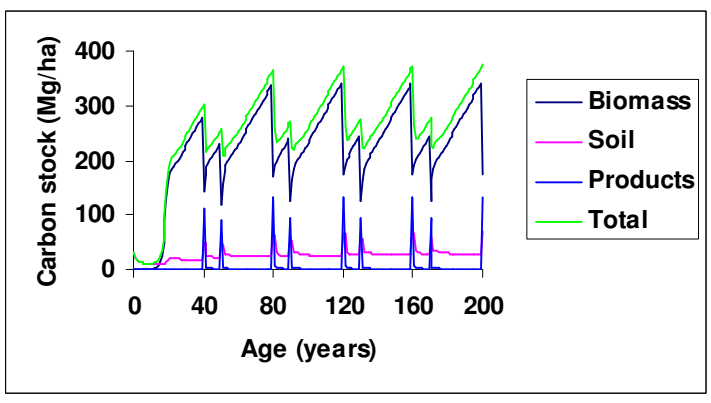

f) I. wombulu

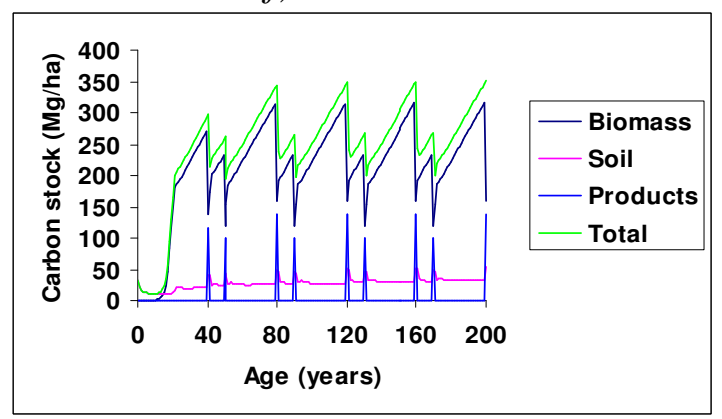

h) T. abut

Figure 3. Carbon sequestration in the different agroforests with partial cut every 40 years, and a shut gap of 10 years, for five cycles 


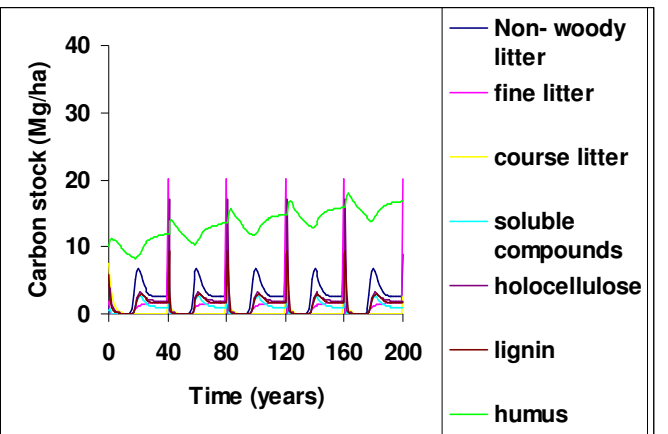

a) A. lepidophyllus

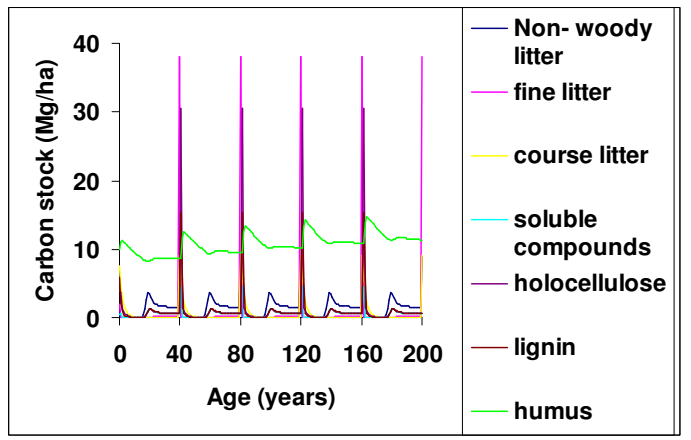

c) D. edulis

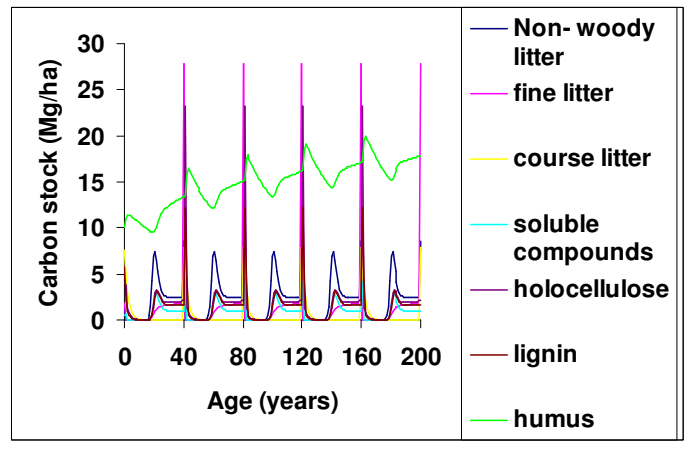

e) I. gabonensis

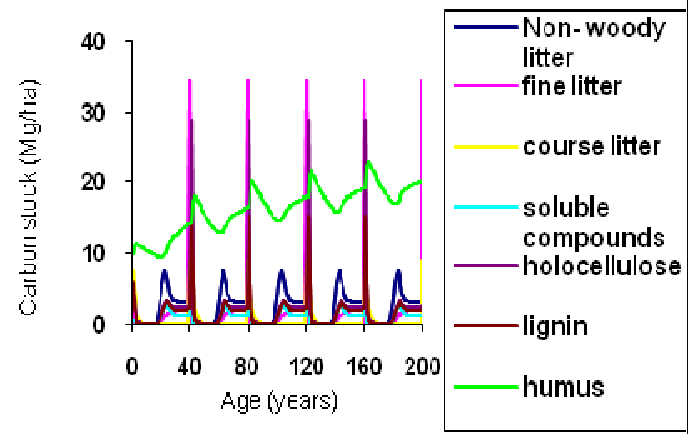

g) R. heudelotii

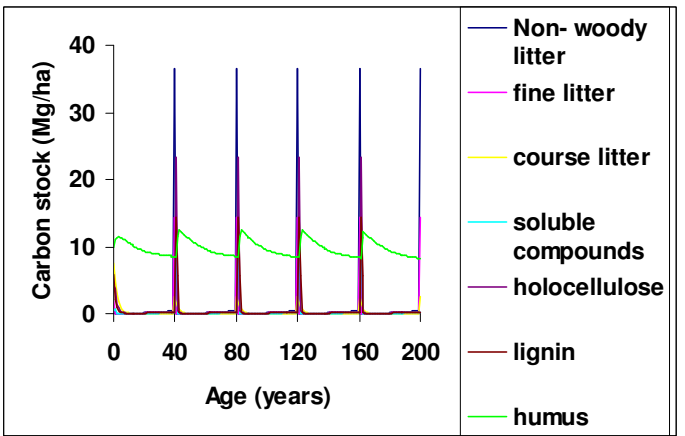

b) C. lepidota

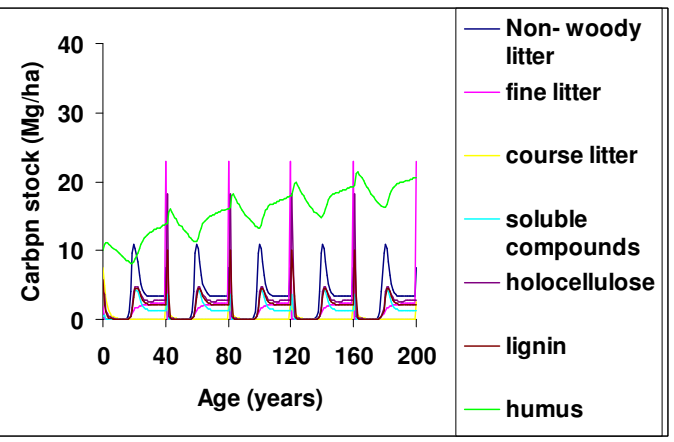

d) G. cola

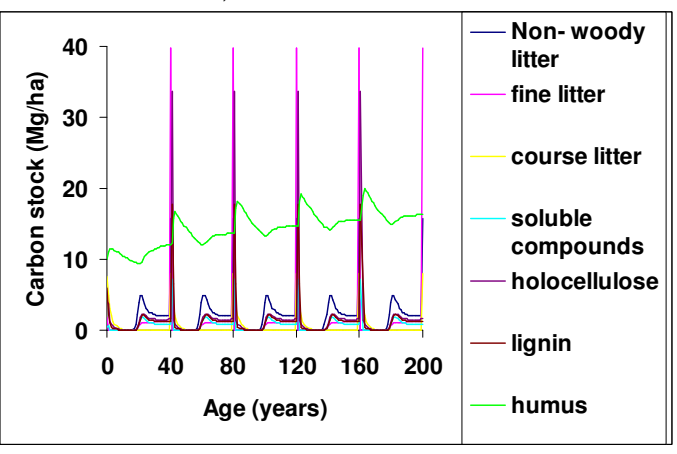

f) I. wombulu

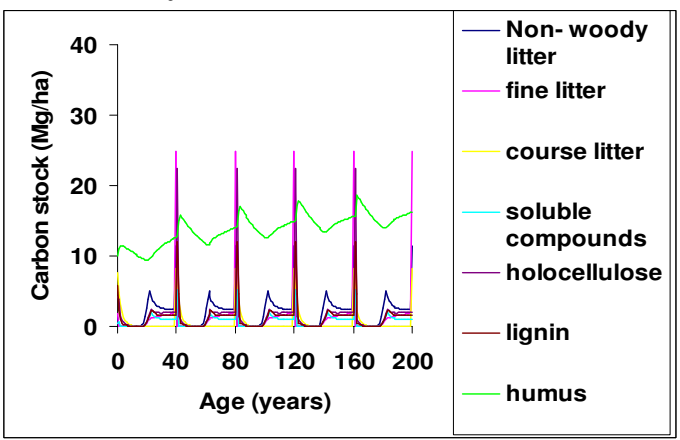

h) T. abut

Figure 4. Soil carbon dynamics in the different agroforests with complete rotation every 40 years, for five cycles 


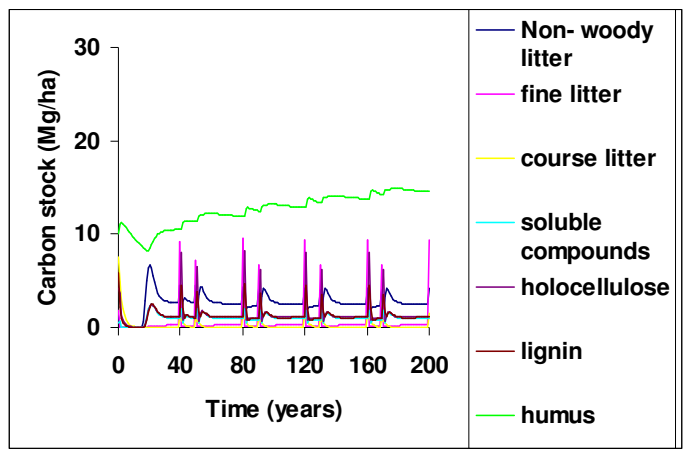

a) A. lepidophyllus

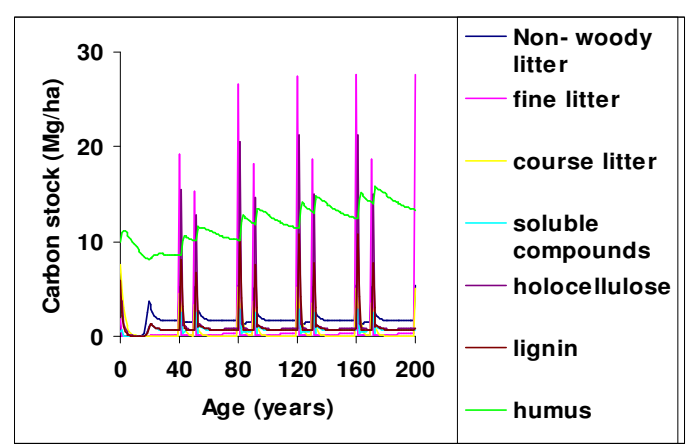

c) D. edulis

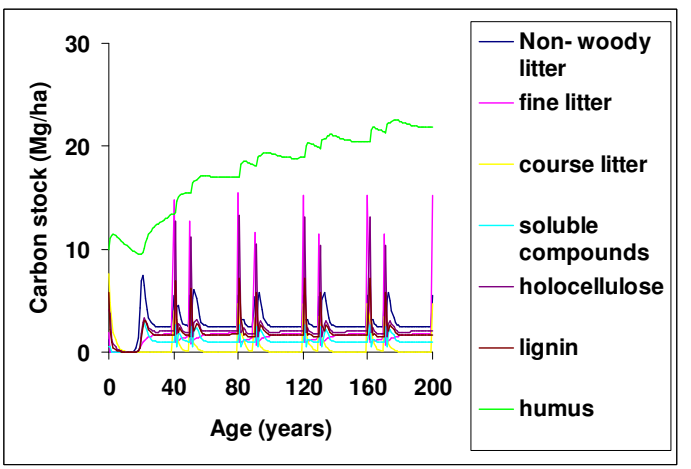

e) I. gabonensis

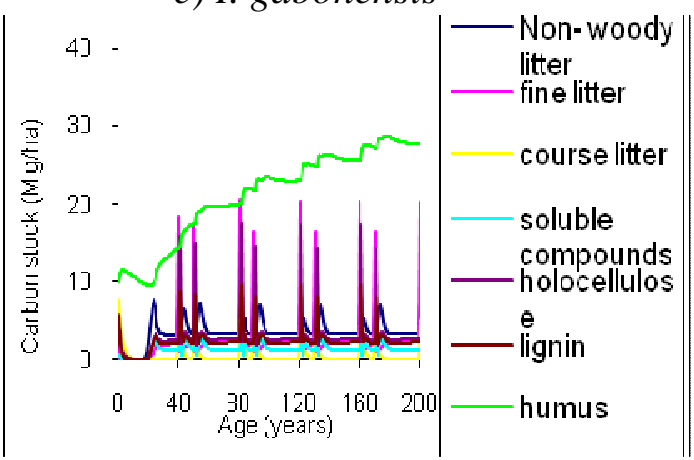

g) R. heudelotii

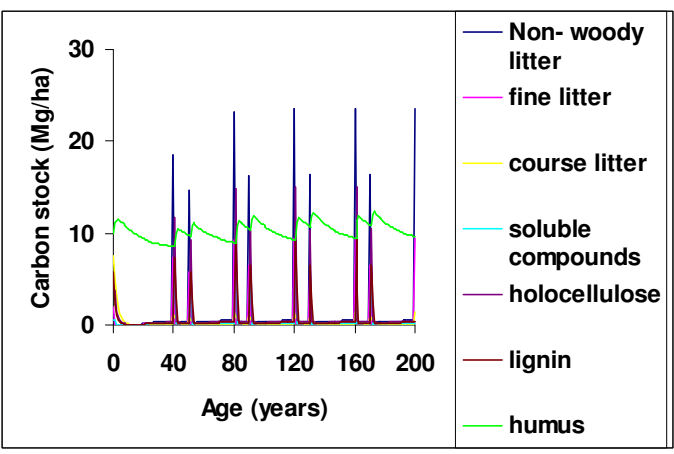

b) C. lepidota

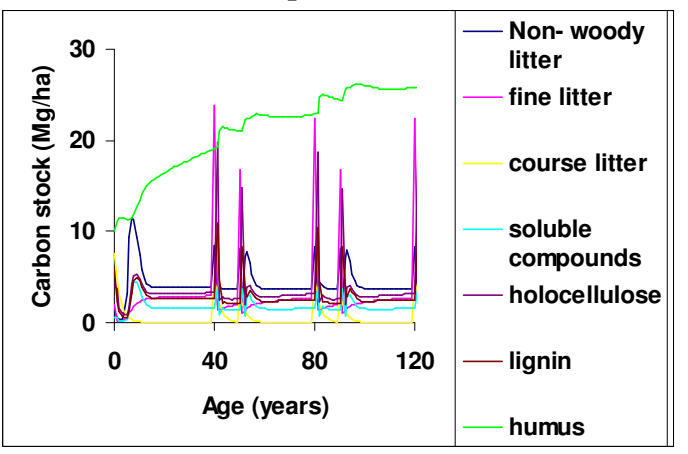

d) G. cola

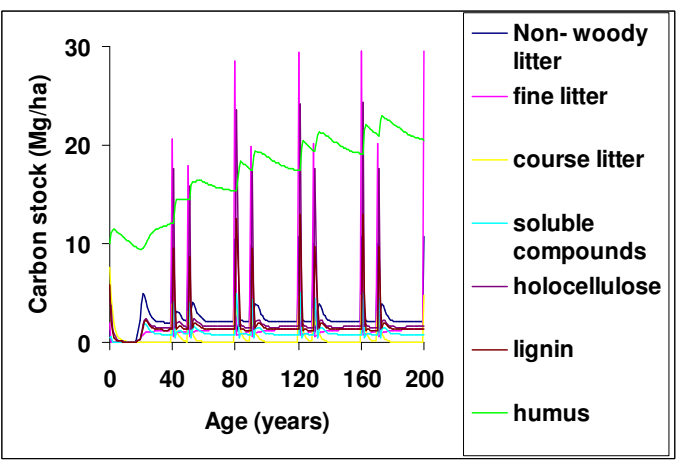

f) I. wombulu

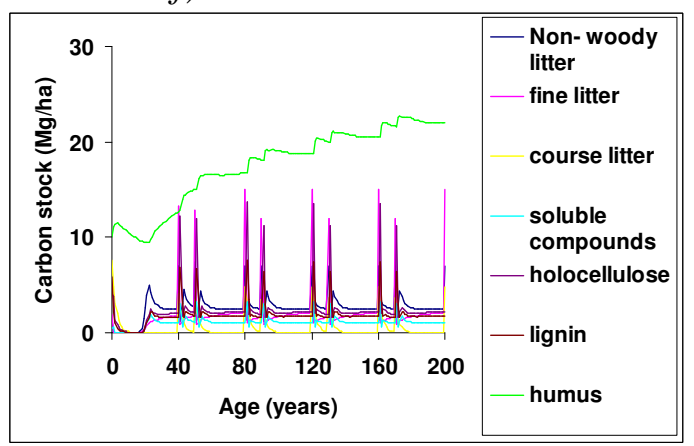

h) T. abut

Figure 5. Soil carbon dynamics in the different agroforests with partial cut every 40 years and a shunt gap of 10 years, for five cycles 


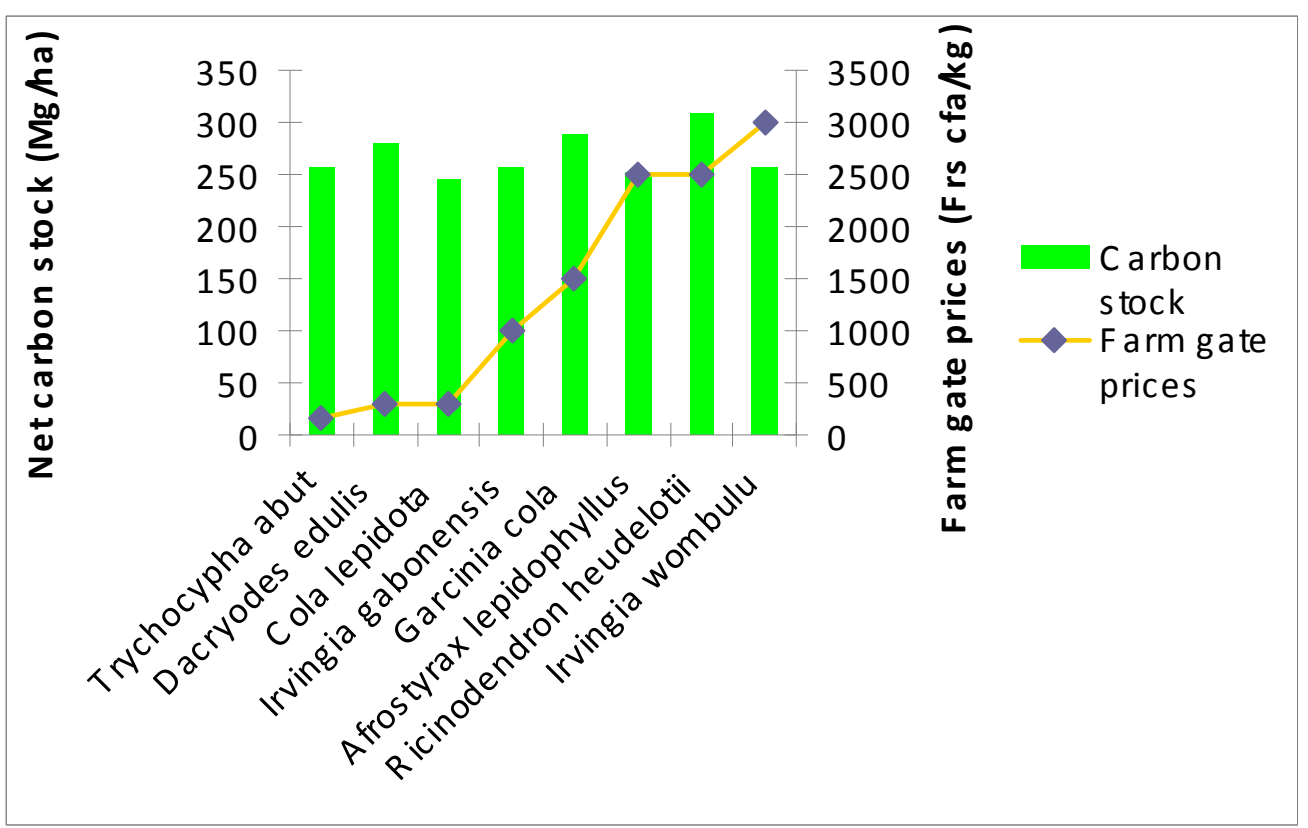

Figure 6. $\boldsymbol{a}$. Net carbon stock and income generating potential with complete rotation cut of eight NTFPs

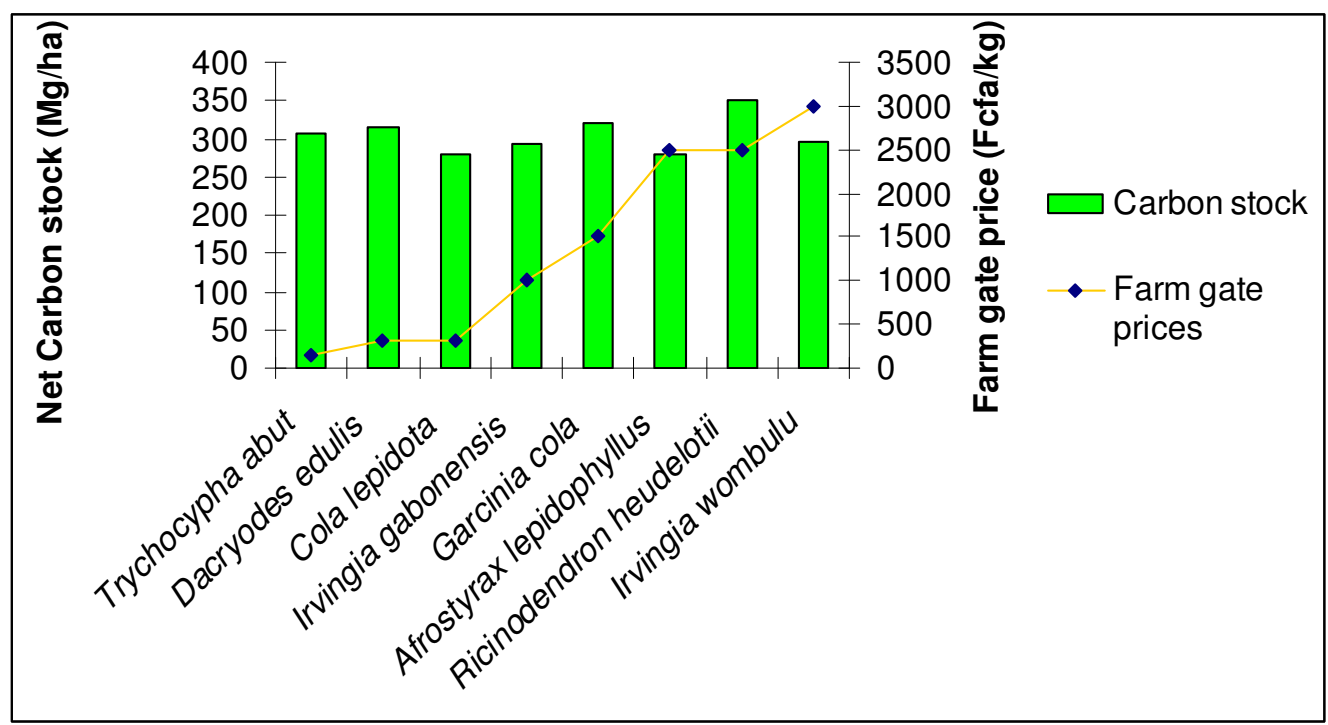

Figure 6. $\boldsymbol{b}$. Net carbon stock and income generating potential in partial cut of eight NTFPs

Table 2 shows the mean carbon stocks and accumulation rates of the different agroforests after five rotations. Mean carbon stocks for complete rotation had a range of 275.65 to $399.59 \mathrm{Mg} \mathrm{C} \mathrm{ha}^{-1}$, and mean carbon accumulation rates in this case had a range of 6.89 to $8.48 \mathrm{Mg} \mathrm{C} \mathrm{ha}^{-1} \mathrm{yr}^{-1}$. Under the partial cut regime, mean carbon stocks ranged from 311.40 to $380.51 \mathrm{Mg} \mathrm{C} \mathrm{ha}^{-1}$ and the mean rate of carbon accumulation in the different ecosystems ranged from 7.78 to $9.51 \mathrm{Mg} \mathrm{C} \mathrm{ha}^{-1} \mathrm{yr}^{-1}$. Ricinodendron heudelotii had the highest mean sequestration rate and Cola lepidota the least, under both management regimes. 
Figures $6 a$ and $6 b$ shows species prioritization, and the carbon credits value of the different species under the two management regimes. Irvingia wombulu had the highest farm-gate price of 3000 frs cfa (\$6.67) per kilogram while Trichocypha abut had the least, 150 frs cfa $(\$ 0.33)$ per $\mathrm{Kg}$. Carbon credits potentials of the agro-ecosystems studied ranged from US\$ 2756 to $\$ 3264 \mathrm{ha}^{-1}\left(1,102,400\right.$ to $1,305,600$ frs cfa ha $\left.{ }^{-1}\right)$ for each complete rotation while with partial cut, the range was US\$3114 to $3678 \mathrm{ha}^{-1}$ $\left(1,245,600\right.$ to $\left.1,471,200 \mathrm{frs} \mathrm{cfa} \mathrm{ha}^{-1}\right)$ per rotation $(1 \mathrm{USD}=400 \mathrm{frs} \mathrm{cfa})$.

Table 1. a. Soil carbon fractions of species with complete rotation every 40 years

\begin{tabular}{c|c|c|c|c|c|c|c}
\hline Species & $\begin{array}{c}\text { Non- } \\
\text { woody } \\
\text { litter }\end{array}$ & $\begin{array}{c}\text { Fine } \\
\text { litter }\end{array}$ & $\begin{array}{c}\text { Soil carse } \\
\text { litter }\end{array}$ & $\begin{array}{c}\text { Soluble } \\
\text { compounds }\end{array}$ & $\begin{array}{c}\text { Holo- } \\
\text { cellulose }\end{array}$ & Lignin & Humus \\
\hline $\begin{array}{c}\text { Afrostyrax. } \\
\text { lepidophyllus }\end{array}$ & 12.11 & 22.93 & 7.86 & 1.00 & 1.94 & 1.60 & 17.40 \\
$\begin{array}{c}\text { Cola lepidota } \\
\text { Dacryodes edulis }\end{array}$ & 7.76 & 20.66 & 7.82 & 0.94 & 1.82 & 1.51 & 17.30 \\
$\begin{array}{c}\text { Garcinia cola } \\
\text { Irvingia }\end{array}$ & 12.97 & 20.98 & 9.20 & 0.78 & 1.72 & 1.38 & 13.93 \\
gabonensis & 8.61 & 27.81 & 7.54 & 1.53 & 3.22 & 2.61 & 25.62 \\
$\begin{array}{c}\text { Irvingia } \\
\text { wombulu }\end{array}$ & 12.21 & 25.11 & 7.89 & 1.01 & 2.08 & 1.69 & 17.85 \\
$\begin{array}{c}\text { Ricinodendron } \\
\text { heudelotii }\end{array}$ & 11.42 & 34.49 & 170.11 & 1.33 & 2.63 & 2.16 & 28.67 \\
Trichocypha abut & 11.50 & 24.76 & 8.26 & 0.99 & 2.06 & 1.67 & 16.23 \\
\hline
\end{tabular}

Table 1. b. Soil carbon fractions of species with partial cut every 40 years and a shunt gap of 10 year

\begin{tabular}{c|c|c|c|c|c|c|c}
\hline Species & Non- & $\begin{array}{c}\text { Fine } \\
\text { litter }\end{array}$ & $\begin{array}{c}\text { Soarse carbon fraction (Mg C/ha) } \\
\text { litter }\end{array}$ & $\begin{array}{c}\text { Soluble } \\
\text { compounds }\end{array}$ & $\begin{array}{c}\text { Holo- } \\
\text { cellulose }\end{array}$ & Lignin & Humus \\
& litter & & & & & & \\
\hline $\begin{array}{c}\text { Afrostyrax. } \\
\text { lepidophyllus }\end{array}$ & 6.64 & 9.88 & 4.73 & 0.94 & 1.76 & 1.47 & 18.36 \\
$\begin{array}{c}\text { Cola lepidota } \\
\text { Dacryodes edulis }\end{array}$ & 5.05 & 10.58 & 4.76 & 0.94 & 1.77 & 1.47 & 19.62 \\
$\begin{array}{c}\text { Garcinia cola } \\
\text { Irvingia }\end{array}$ & 8.36 & 12.01 & 5.31 & 0.78 & 1.80 & 1.43 & 17.08 \\
$\begin{array}{c}\text { gabonensis } \\
\text { Irvingia }\end{array}$ & 5.58 & 15.21 & 4.58 & 1.52 & 3.14 & 2.55 & 29.75 \\
$\begin{array}{c}\text { wombulu } \\
\text { Ricinodendron } \\
\text { heudelotii }\end{array}$ & 7.39 & 14.27 & 4.71 & 1.02 & 2.12 & 1.72 & 21.79 \\
Trichocypha abut & 7.04 & 20.36 & 98.94 & 1.36 & 2.38 & 2.30 & 36.48 \\
\hline
\end{tabular}


Table 2. Mean carbon stocks and carbon accumulation rates after five rotations of the different agroforest ecosystems

\begin{tabular}{|c|c|c|c|c|}
\hline \multirow[t]{3}{*}{ Species } & \multicolumn{4}{|c|}{ Mean carbon stocks per rotation } \\
\hline & \multicolumn{2}{|c|}{ Complete rotation } & \multicolumn{2}{|c|}{ Partial cut } \\
\hline & $\begin{array}{c}\text { Carbon stock } \\
\text { (Mg C/ha) }\end{array}$ & $\begin{array}{c}\text { Carbon } \\
\text { accumulation } \\
\text { rate }(\mathrm{Mg} \mathrm{C} / \mathrm{ha} / \mathrm{yr})\end{array}$ & $\begin{array}{c}\text { Carbon stock } \\
\text { (Mg C/ha) }\end{array}$ & $\begin{array}{c}\text { Carbon } \\
\text { accumulation } \\
\text { rate }(\mathrm{Mg} \mathrm{C} / \mathrm{ha} / \mathrm{yr})\end{array}$ \\
\hline Cola lepidota & 275.65 & 6.89 & 311.48 & 7.78 \\
\hline $\begin{array}{l}\text { Afrostyrax } \\
\text { lepidophyllus }\end{array}$ & 283.60 & 7.09 & 311.40 & 7.78 \\
\hline Irvingia wombulu & 288.78 & 7.21 & 325.78 & 8.14 \\
\hline $\begin{array}{l}\text { Irvingia } \\
\text { gabonensis }\end{array}$ & 288.83 & 7.22 & 324.75 & 8.11 \\
\hline Trichocypha abut & 298.77 & 7.46 & 337.93 & 8.44 \\
\hline Dacryodes edulis & 311.28 & 7.78 & 344.91 & 8.62 \\
\hline Garcinia cola & 318.94 & 7.97 & 352.53 & 8.81 \\
\hline $\begin{array}{l}\text { Ricinodendron } \\
\text { heudelotii }\end{array}$ & 339.59 & 8.48 & 380.51 & 9.51 \\
\hline
\end{tabular}

\section{Discussion}

The range of total carbon stocks of both complete and partial cut obtained in this study falls within the range obtained by other authors such as Delaney et al. (1997) and Shin et al. (2005) and could be explained by intrinsic differences in the plants, as well as the management system simulated. Plant age, wood density and tree volume are some determinants of carbon stocks in plants. In the different agroforests studied, all these factors have contributed to give the observed trend. Since all agroforests were modeled based on the same time scale, the contribution of time to the observed differences is bound to be minimal. Thus the final observed stocks are as a result of synergistic effects of volume increment and wood density as the main determinants. Volume increment gives a measure of the biomass growth while wood density determines the actual proportion of carbon represented in plant biomass, and both were found to be inversely proportional. The highest stocks in $R$. heudelotii can be explained by the very high rate of diameter increment in this species. It had the highest current annual increment of all species studied, and consequently the highest carbon stocks, in spite of its relatively low wood density. This is consistent with the findings of Vieira et al. (2005) who reported higher carbon stocks in plants with a higher rate of diameter increment. Wood density also influenced the observed pattern, probably by influencing the current annual increment of the species. Apart from R. heudelotii, carbon sequestration potentials in the other NTFPs reflect an interplay between wood density and diameter increment. Thus Garcinia cola with the highest wood density $(0.78 \mathrm{~g} / \mathrm{cm} 3)$, has the second sequestration potential after $R$. heudelotii, with complete rotation. These findings are consistent with those of Rahayu et al. (2005) who reported higher carbon stocks in land use systems consisting of trees with high wood densities compared to those with low wood densities and similar diameters, implying a direct role for diameter increment in carbon sequestration.

Net carbon stocks in biomass were higher for most of these species than average biomass of moist tropical forests $\left(241 \mathrm{Mg} \mathrm{ha}^{-1}\right)$. Pure stands of high-density trees are bound to have higher carbon stocks than those in mixed stands of tropical forests, with most having low wood density and diameters. Moreover, logging of timber reduces 
carbon stocks of the tropical forests (Masera et al., 2003). Carbon stocks in biomass were constant at the end of each complete rotation, but increased progressively under the partial cut regime. This might be principally due to the management system. For the complete rotation there is complete clear-felling every 40 years, whereas in partial cut, during each cycle, half of the plantation is cut and later regenerate while the other half continues to accumulate carbon, and the rotation cycle will only be complete ten years later when the newly established half of the plantation is already a net carbon sink. The carbon stocks at the end of the shunt gap thus include carbon stocks of the un-cut section, and carbon accumulated in the replanted section. This system is economically more productive than complete rotation where the whole plantation is clear-felled. Carbon sequestration potentials in the current study are closely related to findings by Kotto-Same et al. (1997), Niles et al. (2002), Vieira et al. (2005).

Soil carbon stocks of most species were within the range obtained by Lasco et al. (2005) who reported a range of 30.7 to $106.2 \mathrm{Mg} \mathrm{C} \mathrm{ha}^{-1}$ for soil carbon in a selectively logged Dipterocarp forest while Delaney et al. (1997) found a range of 73 to $319 \mathrm{Mg} \mathrm{C}$ $\mathrm{ha}^{-1}$ in a study carried out in Venezuela. Generally, organic matter is added to the soil during each rotation, accounting for the increase in soil carbon of the species studied, across the different rotation cycles. During the first 3 years in both management regimes, there is a drop in soil carbon. This could be attributed to the increased decomposition and leaching as well as low inputs primarily from litter and roots turnover, following site disturbances that accompany establishment of the agroforests. At the end of the first complete rotation, there is a sharp increase in soil carbon, higher than the case for partial cut. This may be due to the higher organic inputs following complete clear-felling resulting in peaks of coarse litter, soluble compounds, and fine litter and other component at the end of each rotation. These components are however short-lived due to rapid decomposition, increase in microbial respiration, biological oxidation and consequently, most of the carbon is emitted to the atmosphere while soluble compounds are rapidly leached. Humus is therefore the most permanent component of soil carbon. The lower soil carbon stocks in the current study with partial cut by the fifth cycle as compared to complete rotation may equally be as a result of the management system, which influence organic matter inputs, decomposition and retention of carbon in soils. In Afrostyrax lepidophyllus agroforest for instance, with complete rotation, soil carbon increases from $31.15 \mathrm{Mg} \mathrm{C}^{-1}$ to $59.41 \mathrm{Mg} \mathrm{C}^{-1}$ in 40 years (end of rotation), with the addition of $28.26 \mathrm{Mg} \mathrm{C}^{-1}$ from the cut plants and litter turnover. 10 years later, there is actually a loss of $59 \%\left(18.41 \mathrm{Mg} \mathrm{C} \mathrm{ha}^{-1}\right)$ of original soil carbon but by the next rotation, net carbon added to the soil increases to 61.24 $\mathrm{Mg} \mathrm{C} \mathrm{ha}^{-1}$, a rate of $0.75 \mathrm{Mg} \mathrm{C} \mathrm{ha}^{-1} \mathrm{yr}^{-1}$ between rotations. With partial cut, the corresponding sequestration rate over the same period is $0.07 \mathrm{Mg} \mathrm{C} \mathrm{ha}^{-1} \mathrm{yr}^{-1}$ between rotations.

Partial cuts allow for slower accumulation of organic matter in the soil since organic inputs at each half cut are less, coupled with higher rates of decomposition and leaching than with complete rotation, and resulting to lower carbon retention in soils. The trend of soil carbon sequestration in the two management regimes is thus in conformity with the findings of Pretty et al. (2002). They reported net carbon sequestration increases with management practices that increase plant material returned to, and retained in the soil. But the rates of carbon sequestration in soils (1.40 to $6.11 \mathrm{Mg} \mathrm{ha}^{-1}$ with complete rotation and 1.03 to $3.92 \mathrm{Mg} \mathrm{ha}^{-1}$ under the partial cut regime) are contrary to the 
findings of Palm et al. (2000) who reported insignificant variation in soil carbon stocks due to the low sequestration potential in tropical soils ( 0.3 to $\left.0.6 \mathrm{Mg} \mathrm{ha}^{-1} \mathrm{yr}^{-1}\right)$.

Consistently, total soil carbon stocks are less than carbon stored in plant biomass. Furthermore, the ratio of soil to biomass carbon is highly dependent on the end uses of the cut wood. While $95 \%$ of the cut wood is exported from the site and used as energy for the other species, further reducing organic inputs to soil and resulting in lower soil sequestration. In $R$. heudelotii, the wood quality is very poor for fuel wood and when cut, is often left onsite to decay, resulting in an approximately equal ratio between biomass and soil carbon under both management regimes. These results for soil carbon in $R$. heudelotii corroborate studies carried out by Delaney et al. (1997) who reported higher carbon stock in soils as opposed to plant biomass, in three out of five life zones in Venezuela, in which felled wood was allocated to soil carbon. Tschakert et al. (2007) also reported that soils in an evergreen Tropical rainforest in Panama accounted for 45 to $73 \%$ of total carbon.

The rate of carbon accumulation varied between species and the management system. The rates of sequestration are dependent on the combined effect of the wood densities and volume increments of the species, and are higher with partial cut since this system favours carbon accumulation in biomass, and the higher soil sequestration rates with complete rotation are not enough to compensate. These findings are consistent with those of Niles et al. (2002) who reported carbon accumulation rates of 2.5 to $5.0 \mathrm{Mg} \mathrm{C}$ $\mathrm{ha}^{-1} \mathrm{yr}^{-1}$ for humid tropical regions, but are contrary to those of Kotto-Same et al. (1997) for an 8 year old fallow in Cameroon (28.12 $\left.\mathrm{Mg} \mathrm{C} \mathrm{ha}^{-1} \mathrm{yr}^{-1}\right)$, in spite of similar climatic and site characteristics, similar land use trends as well as similarity in the flora of the different sites.

Irvingia wombulu was the most prioritized species due to its high farm-gate price, while T. abut was the least prioritized. Farm gate prices were the preferred index of prioritization because they are the most authentic measure of the income farmers realize from sales of their produce. For a 'best ecology and economy' scenario, I. wombulu was the species of choice, followed by $R$. heudelotii, while $T$. abut was the least. This is because although $T$. abut had a high carbon sequestration potential, its income generating potential was very low. These findings are similar to those of Niles et al. (2002) who reported that for CDM reforestation projects, NTFPs are vital as opposed to established timber species, for both technical and rural livelihoods purposes.

The higher potential carbon credit values of the different agroforests with partial cut as opposed to complete rotation is due to the higher rates of carbon accumulation under the partial cut regime. Moreover, this potential value of carbon in the international market will serve as added value to agroforest systems, in addition to social, economic and environmental benefits, if implemented appropriately (IPCC, 2001). Coupled with prioritization, species with best ecological and economic potentials can be chosen for climate change mitigation schemes.

\section{Conclusion}

NTFPs have significant potentials in climate change mitigation through carbon sequestration. Generally, carbon sequestration potentials depended on both wood density and volume increments. Management regimes are relevant to any agroforest carbon project. Partial cut could be tailored to ensure net sequestration and used in preference to complete rotation to mitigate climate change and improve rural 
livelihoods. These results would aid policy makers, researchers and investors in Clean Development Mechanism projects.

Acknowledgements. We thank Masera, O.R., Garza-Caligaris, J.F., Kanninen, M., Karjalainen, T., Liski, J., Nabuurs, G.J., Passinen, A., De Jong, B.H.J. and Mohren, G.M.J. for providing us with a copy of the CO2FIXV.2 software, and the farmers/communities in Manyu Division where this study was carried out.

\section{REFERENCES}

[1] Bele, M.Y. (2003): Inventory, distribution and uses of the Annonaceae of Mount Cameroon. - M.Sc. thesis, University of Buea, 147 pp.

[2] Boateng, S.A. (2005): How much carbon do Ghana's Teak Plantations sequester? - ITTO Tropical Forest Update 15(4): 22-23.

[3] Brennan, S., Wittgott, J. (2005): Environment, the science behind the stories. - Macgraw Hills.

[4] Cacho, O.J., Hean, R.L., Wise, R.M. (2003): Carbon accounting methods and reforestation incentives. - Austrialian Journal of Agriculture and Resource Economics 47(2): 153-179.

[5] Climate Network Africa (2004): Contraction and Convergence. - Workshop Report, Nairobi. 33 pp.

[6] Delaney, M., Brown, S., Lugo, A.E., Torres-Lezama, A., Quintero, N.B. (1997): The distribution of organic carbon in major components of forests located in five life zones of Venezuela. - Journal of Tropical Ecology 13: 697-708.

[7] Djeumo, A. (2001): Development of community forests in Cameroon: Origins, Current situation and Constraints. - Rural Development Forestry Network Paper 25(b): 1-17.

[8] Eba'a Atyi, R. (2000): TROPFOMS: A Decision Support Model for Sustainable Management of South-Cameroon's Rain forests. - TROPEBOS International Publication; Cameroon Series 2. $202 \mathrm{pp}$.

[9] ECCM (2002): Carbon sinks in the Amazon. - The Edinburg Centre for Carbon Management. Technical Note. 5 pp.

[10] Elbakkidze, L., Mccarl, B.H. (2007): Sequestration offsets versus direct emission reductions: consideration of environmental co-effects. - Ecological Economics 60(3): 564-571.

[11] Fomete, T. (2001): The forestry taxation system and the involvement of local communities in Forest Management in Cameroon. - Rural Development Forestry Network Paper 25(b): 17-27.

[12] Gallardo, J.F., Saavedra, J., Martin-Patino, T., Millan, A. (1987): Soil Organic matter determination. - Communications in Soil Science and Plant analysis 18(6): 699-707.

[13] Gisel, R., Sandra, B., Jonathan, C., Ariel, L.E. (1992): Wood densities of tropical species. - US department of agriculture, Forest Service, South West Experimental Station. New Orleans. 15 pp.

[14] Glenday, J. (2006): Carbon storage and emission offset potential in an east African Tropical Rain forest. - Forest Ecology and Management 235(1-3): 72-83.

[15] Gronkvist, S., Mollerstern, K., Pingoud, K. (2006): Equal opportunity for Biomass in greenhouse gas accounting of $\mathrm{CO} 2$ capture and storage: a step towards more cost effective climate change mitigation regimes. - Mitigation and Adaptation Strategies for Global Change 11(5-6): 1083-1096.

[16] Houghton, R.A. (2005): Above ground forest biomass and the global carbon balance. Global Change Biology 11: 945-958.

[17] Karjalainen, T., Pussinem, A., Liski, J., Nabuurs, G., Erhard, M., Eggers, T., Sonnteg, M., Mohren, G.M.J. (2002): An approach towards an estimate of the impact of forest 
management and climate change on the European Forest Sector carbon budget: Germany as a case study. - Forest Ecology and Management 162: 87-103.

[18] Kotto-Same, J., Woomer, P.L., Appolinaire, M., Louis, Z. (1997): Forest dynamics in slash and burn agriculture and landuse alternatives of the humid forest zone in Cameroon. - Agiculture, Ecosystem \& Environment 65(3): 245-256.

[19] Lasco, R.D., MacDicken, K.A., Pulhin, F.B., Guillermo, I.Q., Sales, R.F., Cruz, R.V.O. (2005): Carbon stocks in a selectively logged Dipterocarp forest. - Journal of Tropical Forest Science 18(14): 166-172.

[20] Masera, O.R., Garza-Caligaris, J.F., Kanninen, M., Karjalainen, T., Liski, J., Nabuurs, G.J., Passinen, A., De Jong, B.H.J., Mohren, G.M.J. (2003): Modelling carbon sequestration in Afforestation, agroforestry and forest management projects: the CO2FIXV.2 Approach. - Ecological Modelling 164: 177-199.

[21] Matthiesen, M.K., Lamey, F.J., Selinger, L.B., Olson, A.F. (2005): Influence of loss-onignition temperature and heating time on ash content of compost and manure. Communications in Soil Science and Plant Analysis 36(17-18): 2561-2573.

[22] Mccarl, B.A., Metting, F.B., Rice, C. (2007): Soil carbon sequestration. - Climatic Change 80(1-2): 1-3.

[23] Mccarl, B.A., Sands, R.D. (2007): Competitiveness of terrestrial Greenhouse Gas offsets: Are they a bridge to the future. - Climatic Change 80(1-2): 109-126.

[24] Mutuo, P.K., Cadisch, U., Albrecht, A., Palm, C.A., Verchot, L. (2005): Potential of Agroforestry for carbon sequestration and mitigation of greenhouse gas emissions from soils in the tropics. - Nutrient Cycling in Agroecosystems 71(1): 43-54.

[25] Nabuurs, G.J., Garza-Caligaris, J.F., Kanninen, M., Karjalainen, T., Lapvetelainen, T., Liski, J., Masera, O.R., Mohren, G.M.J., Pussinen, A., Schelhaas, M.J. (2001): CO2FIXV2.0 - Manual of a model for quantifying carbon sequestration in forest ecosystems and wood products. - ALTERRA Report xx. Wageningen, 2001. 48pp.

[26] Niles, J.O., Btown, S., Pretty, J.N., Ball, A., Fay, J. (2000): Potential carbon mitigation and income in developing countries from changes in use and management of Agricultural and forest lands. - Royal Society Transactions A: Carbon, Biodiversity, Conservation and Income. 24pp.

[27] Nkwatoh, A.F. (2000): Evaluation of trade in non-timber Forest Products in the Ejagham forest reserve of Southwest Cameroon. - Ph.D. Thesis, university of Ibadan.

[28] Palm, C.A., Van Noordwijk, M., Woomer, P.L., Alegre, J., Castilla, C., Cordeiro, D.G., Hairiah, K., Kotto-Same, J., Moukam, A., Njomgang, R., Ricse, A., Rodrigues, V. (2000): Carbon losses and sequestration potentials of alternatives to slash and burn agriculture. - In: The biology and fertility of tropical soils. TSBF, Nairobi.

[29] Pretty, J.N., Ball, A.S., Xiaoyun, L., Ravindranath, N.H. (2002): The role of sustainable agriculture and renewable resource management in reducing greenhouse gas emissions and increasing sinks in India and China. - Philosophical Transactions of the Royal Society Series A 360: 1741-1761.

[30] Pretty, J.N, Noble, A.D., Bossio, S., Dixon, J., Hine, F.W.T., Penning De Vries, Morison, J.I.L. (2006): Resource conserving agriculture increases yields in developing countries. Environmental Science and Technology 40: 1114-1119.

[31] Rahayu, S., Lusiana, B., Van Noordwijk, M. (2005): Above ground carbon stock assessment for various land use systems in Nunukan, East Kalimantan. - In: Lusiana, B., Van Noordwijk, M. and Rahayu, S. eds. (2005): Carbon in Nunukan: A spatial Monitoring approach and modeling. - Report from carbon monitoring team of forest resource Management and Carbon sequestration (FORMACS) project. Bogor, Indonesia, World Agroforestry Centre, SEA Regional Office. 21-33.

[32] Shin, M.Y., Miah, M.D., Lee, K.H. (2007): Potential contribution of the forest sector in Bangladesh to carbon sequestration. - Journal of Environmental Management 82(2): 260276. 
[33] Stern, N. (2006): Stern Review report on the economics of climate change. - HM Treasury, London. 575pp.

[34] Tschakert, P., Coomes, O.T., Potvin, C. (2007): Indigenous livelihoods, slash and burn agriculture and carbon stocks in Eastern Panama. - Ecological Economics 60: 807-820.

[35] Vieira, S., Trumbone, S., Carnargo, P.B., Sethorst, D., Chambers, J.Q., Higuchi, N., Martinelli, L.A. (2005): Slow growth rates of Amazonian trees: Implications for carbon sequestration. - PNAS 102(51): 18502-18507. 